\title{
Frankel and Rose's Introduction to the Endogeneity of Optimality: A Model Limited to the European Monetary Experience
}

Received: 09.01.2021

Available online: 28.06.2021

\section{Alban Mathieu*}

\section{Abstract}

This article discusses Frankel and Rose's (1997, 1998) introduction to endogeneity, which was the result of scrutinizing the optimal currency area (OCA) theory through the evaluative lens of European monetary integration and unification in the 1990s. It cannot be generalized to another monetary union. The development of endogeneity interrelates five different criteria (common currency; transaction costs; commercial integration; economic convergence; and diversification of production) to argue that the introduction of a common currency leads to economic convergence among the participating countries. Frankel and Rose's choice of analytic criteria arises from empirical studies on European monetary unification, following the OCA framework. The empirical studies found to have influenced the authors can be divided into three themes: the microeconomic benefits of a common currency; the optimality of European countries; and adjustment mechanisms. However, as shown by the selection of certain criteria, the influence of the Emerson report (1990), and the price-stability orientation of fiscal and monetary policies, their proposal only works within the monetary and economic conditions of the future eurozone area.

Keywords: Monetary currency areas, money, endogeneity, European monetary union.

JEL: B20, E42, F33

\section{Introduction}

Erankel and Rose (1997, 1998) were the first to introduce within the optimal currency area (OCA) theory the logic of the endogeneity of optimality using Lucas's critics ${ }^{1}$ (Frankel and Rose, 1997, p. 755). They state that "thus, cyclic correlation is endogenous" (Frankel and Rose, 1997, p. 755) to the establishment of a common currency, since it enables optimality to be achieved within the relevant monetary area. This endogeneity is generated by causal mechanisms from structural change integrating and interrelating certain criteria (Frankel and Rose, 1997, p. 754): because of the microeconomic benefits, the introduction of a common currency increases trade integration between countries belonging to the monetary area, resulting

Docteur en économie, Laboratoire TRIANGLE, Maison des Sciences de l'Homme, 14 Avenue Berthelot, 69007 Lyon.

1 Throughout structural change, agents adjust and shape their behavior. Thus, it is erroneous to predict this behavior from a previous situation. 


\section{Articles}

in them sharing similar business cycles. Instead of analyzing monetary area optimality according to certain criteria, a true theoretical reversal occurs in which optimality is thus produced by the monetary union.

Members of the University of California, ${ }^{2}$ Berkeley, specialists in international economy, macroeconomics, and monetary economics, and Doctors of Philosophy from the Massachusetts Institute of Technology, Frankel and Rose $(1997,1998)$ were inspired by European monetary unification to build their framework, as illustrated by the title of the 1997 article: "Is EMU more Justifiable Ex Post than Ex Ante?" Their objective was also to respond to the works of Eichengreen, Bayoumi, and Krugman on European monetary unification (Frankel and Rose, 1998, p. 1012). These multiple influences between OCA theory and the European monetary experience are accepted. Indeed, the Emerson report (1990) used OCA tools to justify the European currency, while Vincensini and Taugourdeau (2009) wondered if the OCA framework, including Frankel and Rose's works, could have impacted the policy-making choices to realize the monetary union.

However, the influence of this monetary integration on the endogeneity of optimality needs to be examined. If OCA theory is useful for evaluating the optimality of different monetary areas, does the endogeneity, as defined by Frankel and Rose, work once a common currency is established? In other words, is a common currency needed, and sufficient, to initiate the mechanisms leading to optimality? Can we generalize the endogeneity of optimality to other monetary unions? This article builds on causal mechanisms at the foundations of the endogeneity to show its limits and implicit hypotheses.

The article begins by presenting the main criteria and the causal mechanisms
Frankel and Rose's Introduction to the Endogeneity of Optimality

implemented at the foundations of endogeneity. This allows us to demonstrate that these mechanisms select criteria studied within OCA empirical publications on European monetary unification, but they also employ the specific conditions of the EMU to work. Finally, this first interpretation is reinforced by analyzing the hypotheses used by Frankel and Rose. The logic behind the endogeneity, as well as the selected criteria, definitively correspond to the monetary and economic conditions of the European monetary union.

\section{The Endogeneity of Optimality: Explaining the Operation}

Frankel and Rose (1997, 1998), both professors at the University of California, Berkeley, focused their research on regional trade blocs, monetary policy, and exchange risks, with the existence of highly developed financial markets. Leading scholars in this field, they were also active in several institutions of the Federal Reserve, as their participation and invitations testify. For this reason, they knew and used the OCA framework, whose problems consist of evaluating the costs and benefits of participating in a fixed exchange rate regime or a monetary union according to specific criteria. However, the authors used a specific version of the OCA, namely, the one following the Delors report. The latter relied on three hypotheses: non-real wage rigidity; high mobility of capital between monetary areas; and the need to insure price stability (Tavlas, 1993, 1994).

Within this framework, Frankel and Rose were the first to introduce optimality as the result of a process. In so doing, they wanted to respond to the works of Eichengreen and Bayoumi on the optimality of the euro area (1998, p. 1012, 1024) (which represent eight references in the bibliography), but mostly to Krugman (1993). Instead of diversification, the

${ }^{2}$ At the time of publication of these articles. 


\section{Articles}

monetary union produced a synchronization of business cycles, allowing them to affirm that the latter was endogenous (Frankel and Rose, 1997, p. 755). This endogeneity, which leads to optimality, comes from a set of causal mechanisms that we call endogenous causality (EC). By stimulating trade integration, a monetary union triggers business cycle convergence, undermining asymmetric shocks between regions or countries and removing the cost of losing change and monetary policies. Such causality leads to theoretical turmoil within the OCA framework: optimality is produced by the causal relations between criteria. It is no longer a state to evaluate.

Frankel and Rose (1997, p. 753) began by noting the costs and benefits of joining a monetary union. On the one hand, they used the argument put forward by Mundell (1961, p. 658): a common currency reduces transaction costs between countries with different currencies. They even concluded that, when a country has important trade with future EMU members, it should integrate this to reap the microeconomic benefits. On the other hand, they argued, monetary integration means a loss of monetary and change policy. The state can no longer act on the business cycle fluctuations with either the interest rate or exchange rate or the monetary issue. Thus, countries with specific fluctuations give up important stabilizing tools.

Then, Frankel et Rose (1998, p. 1011) integrated two criteria to determine the optimality of such integration: one developed by McKinnon (1963) on the degree of trade integration; and another introduced by Eichengreen and Frieden (1993) and Masson and Taylor (1992) on economic cycle convergence. Tavlas (1994, p. 216) noted that the latter relied on Kenen's argument (1969), according to which countries with similar productive structures are more likely to experiment with symmetrical shocks. Thus, if symmetry exists in the economic fluctuations, the loss of monetary and change policies no longer represents a cost, since the occurrence and the degree of asymmetric shocks are drastically reduced. Frankel and Rose then shifted the discussion to the effects of joining a monetary union:

Our aim in this paper is to link the two issues so as to make a simple point. We argue that a naive examination of historical date gives a misleading picture of a country's suitability for entry into a currency union, since both criteria are inter-related and endogenous. (Frankel and Rose, 1997, p. 754)

The hypothesis behind this statement was that a common currency results in higher trade integration, which, in turn, leads to more correlated business cycles. However, from a theoretical point of view, higher trade integration could also cause a specialization in business cycles. This aspect was underestimated by the two authors, who stated that, if demand shocks predominate, which is intra-industry trade, then business cycles will become more similar. As a result, the question is no longer whether a country has optimal currency area criteria but, conversely, the development of optimality thanks to economic convergence.

Our findings lead to a number of conclusions on the prospects and desirability of EMU. Continued European trade liberalization can be expected to result in more tightly correlated European business cycles, making a common European currency both more likely and more desirable. Indeed, monetary union itself may lead to a further boost to trade integration and hence business cycle symmetry. Countries which join EMU, no matter what their motivation, may satisfy 


\section{Articles}

OCA criteria ex post even if they do not ex ante. (Frankel and Rose, 1998, p. 1010)

The idea is clear: joining a monetary union enables symmetric business cycles to be created endogenously. This argument led Lucas's critics to affirm that the outcome of a policy needs to be evaluated ex post and not ex ante (Frankel and Rose, 1997, p. 755). For this reason, they argued, all of the works assessing the optimality of a monetary union, without considering its effect on business cycles, are erroneous (Frankel and Rose, 1998, p. 1015-16).

From this perspective, Frankel and Rose tried to explain this endogeneity. First, to check the correlation between trade and business cycles, they linked the degree of trade integration and income correlation, with the latter an indicator of business cycles. In other words, higher trade integration increases the demand shocks and countries' aggregated productivity covariance, which improves the consistency of the business cycles.

According to the authors, this process is created by the introduction of a common currency (Frankel and Rose, 1998, p. 1010). It is significant that they did not mention the fixed exchange rate regime as a possibility. In accordance with Mundell (1961), a difference was highlighted, since only a common currency brings specific microeconomic benefits that could affect the degree of trade integration. Indeed, the currency risk disappears, and transaction and information costs are reduced. Better price transparency enables market segmentation to be removed and encourages competition. By eliminating these costs, a monetary union is the only source of higher trade integration, which, in fine, leads to higher business cycle correlation. Thus, joining a monetary union leads to optimality continuously.

Krugman (1993), in a previous article, noted that this synchronization depends on a
Frankel and Rose's Introduction to the Endogeneity of Optimality

diversification of economies. In the same way, the argument developed by Kenen (1969) on the similarity of productive structures required its criterion on the diversification of production to work. If the inverse effect and specialization between countries occur, asymmetry increases (Krugman, 1993, p. 243-4). Krugman considered that, as in the case of the U.S., trade integration would lead to more specialization because of economies of scale. This would result in industrial concentration, since the installation choices of companies depend on arbitrage between transaction costs and concentration benefits: "So a reduction of transaction cost would ordinarily lead to a divergence between regions in terms of their industrial structure, and increased specialization of any particular region" (ibid., p. 245). And yet, this critic did not call into question the most important aspect of endogenous causality: establishing a monetary union impacts business cycles, either by convergence or divergence. It did, however, raise a hypothesis about EC reasoning, namely, of diversification of production.

Endogenous causality corresponds to a set of optimal currency area criteria and hypotheses that interact to provide a causal mechanism removing the possibility of asymmetric shocks between countries with a common currency (Frankel and Rose, 1997, p. 755). It consists of causally putting together OCA criteria developed by the founders of the OCA framework, namely, Mundell, McKinnon, and Kenen. The introduction of a common currency (1) reduces transaction and information costs (2), which increases trade integration (3). This leads to business cycle convergence (4) being developed between countries participating in the monetary union based on the hypothesis that they possess diversified production (5). 


\section{Articles}

De Grauwe and Mongelli (2005) noticed that endogenous causality had been used to develop two other OCA criteria: the insurance principle introduced by Ingram (1962); and flexibility of the labor and production market developed by Mundell (1961). Contrary to the previous reasoning, these criteria do not enable asymmetric shocks to be avoided, only that they be absorbed either through financial transfers or as an adjustment tool.

First, by having the same rules governing the use of financial services or instruments, countries increase their financial integration. This enhances more equal access to these services, regardless of the country or entity concerned. In this way, a common currency improves equality through the use of the same currency on the financial market, especially regarding the ability to borrow at the same interest rate. Moreover, improved capital allocation takes place in the monetary area, leading to higher economic growth. However, the most important effect concerns the possibility for derivatives markets to work as a source of insurance against asymmetric shock. Using the same reasoning as before, monetary unification triggers financial integration, which, in turn, improves the insurance principle and therefore the capacity to insure against asymmetric shock.

Still, it is important to note that this latter criterion, although useful in the case of microeconomic asymmetric shocks, is not unlimited throughout important macroeconomic asymmetric shocks. ${ }^{34}$ Indeed, financial integration could be jeopardized by strong economic divergence. Thus, in order to render risk-sharing useful, a trend toward economic convergence is needed.

In the same way, from a theoretical point of view, a common currency improves the flexibility of the labor and production market. Monetary union builds wage discipline as a policy, leads to price transparency, and encourages competition in goods and services markets. All of these elements reduce the power of employees and employers and enable a decentralization of wage negotiation. However, as with the insurance principle, this criterion does not promote economic convergence; it is merely a means to deal with asymmetric shock.

\section{A Causality under Influence: Empirical Cases on the Economic and Monetary Union}

Endogenous causality (EC) has been used to explain how to achieve optimality through the European monetary union. However, far from simply being a theoretical tool using OCA criteria, its formulation was influenced by empirical works on European monetary unification following the publication of the Delors report. Jonung and Dréa (2010) carried out a bibliometric study on the works of American economists of which OCA theory was part. Figure 1 (below) depicts the list of anglophone publications. ${ }^{5}$ It is apparent that the first papers were multiplied after 1989, while we assist their production comes to an end when monetary unification occurs.

\footnotetext{
${ }^{3}$ Based on the hypothesis that two economies diverge in their reaction because of a shock at one point but also in the future.

${ }^{4}$ Here, we can see the advantage of fiscal transfers on financial transfers because they are automatic and do not constitute a debt to be repaid. However, these transfers need stronger political integration than under a common currency.

${ }^{5}$ Jonung and Dréa (2010) affirm that these works were the first to reconsider the OCA theory.
} 
Figure 1: Works published in the euro area using OCA theory

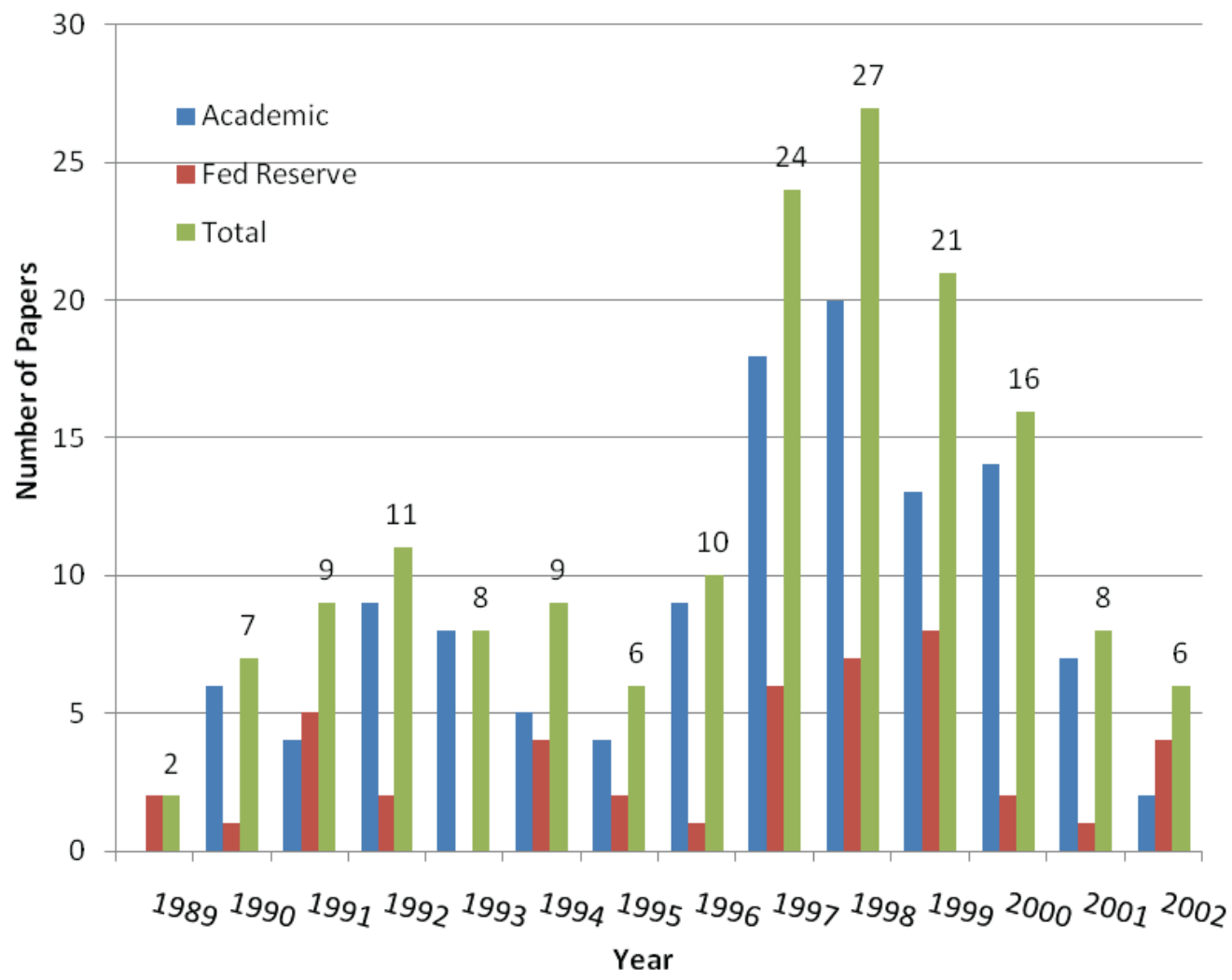

(Jonung, Dréa, 2010, p. 8)

Endogenous causality (EC) took the economic and institutional characteristics shape within optimal currency area (OCA) of the European monetary area. These empirical publications on European monetary unification. Among these studies, EC consists of selecting and causally interacting the OCA criteria that apply and work in the euro area. According to Frankel and Rose (1998, p. 1011), four OCA criteria emerge from the OCA literature: trade volume; similarity of shocks and cycles; degree of labor mobility; and fiscal transfers. The authors (1998, p. 1011) believed it impossible to judge them separately: "We consider this procedure to be untenable, since the OCA criteria are jointly endogenous."

However, taking inspiration from empirical works, particularly Bayoumi and Eichengreen, Frankel and Rose (1998, p. 1024) implicitly used causal mechanisms require more than a common currency to work: they need specific conditions. Indeed, in the European case there was already a high level of trade integration, diversified economies, developed financial markets, trade agreements, and supranational institutions to insure intergovernmental agreement and coordination of governments.

To back up this claim, we take into account discussions that have influenced the formulation of EC. We have chosen to start with the year 1989 because the OCA empirical works began with publication of the Delors report. It is more difficult to justify starting in 1998, although it does bring together two elements. This date represents the publication 


\section{Articles}

of Frankel and Rose's second article and encompasses working papers published in peer review journals in 1997 or 1998 . However, it is not obvious that Frankel and Rose were aware of these works. It is therefore important to define key characteristics proving that the authors knew about them: affiliation with the same institutions, such as the University of California, Berkeley, or the Federal Reserve; participation in the thesis jury of Blanchard for Rose; publications in the same high-ranking journals, such as the Quarterly Journal of Economics and American Economic Review, or in $\mathrm{NBER}^{6}$ and $\mathrm{CEPR}^{7}$ working papers; papers co-written by one of the authors in journals, or book chapters edited by one of the authors; and mutual quotes in different articles. Selected publications according to these characteristics can be divided into three interdependent subsets from 1989 to 1998: assessment of costs and benefits; optimality of the new monetary area; and mechanisms to deal with asymmetric shocks.

The benefits of a monetary union are microeconomic and can be summarized as a cost reduction throughout exchanges. Eichengreen $(1990 \mathrm{a}, 1991)$ noticed that in a fixed exchange rate regime the disruptive effects of the real exchange rate change would be small but would promote trade, as well as financial integration, since the interest rates would become more similar. In the same way, Eudey (1998) and Klein (1998) affirmed that reducing uncertainty in the variation in exchange rate would diminish the bank services required to prevent it, thereby increasing competition and trade. Furthermore, a monetary union avoids the competitive devaluation between states arising from inflationist spirals and financial market speculation, enabling the interest rate to decrease and thereby stimulating investment.
Using a Mengerian and Hayekian framework with the traditional function of money, Jordan (1997) added that a common currency would limit transaction and information costs because it would facilitate exchanges. To work, the quality of money must be insured, implying that monetary authority must defend price stability to avoid any information distortion arising from a change in prices.

The costs associated with a monetary union are well known from the first article on the OCA framework, as previous authors remind us. A state can no longer use monetary and change policy to adjust its economy in the case of asymmetric shocks on external and internal balances or when the stability of a financial system is threatened. However, Whitt (1997) and Eudey (1998) showed that this loss would not be problematic. On the one hand, autonomous monetary policy is not compatible with high capital mobility and a fixed exchange rate regime such as the European Monetary System (EMS). In accordance with Mundell's triangle, change and monetary policies are no longer autonomous in the presence of high capital mobility (Eichengreen, 1990b; 1991, p. 11). On the other hand, since financial markets speculate on the exchange rate, a common currency would allow this source of negative instability on economic performance to be removed (Buiter, 1995).

Eichengreen (1990a), Fink, and Salvatore (1999), and Eudey (1998) stated that tax and fiscal autonomy would also be reduced. High mobility in the factors of production (capital and labor) and the elimination of trade barriers in Europe would intensify the pressure to implement tax and fiscal convergence. In the event of important taxation in certain countries, the factors of production could move within the monetary area to find better returns. Thus, the state's ability to run a public

\footnotetext{
${ }^{6}$ Research Associate of the National Bureau of Economic Research.

${ }^{7}$ Research Fellow of the Center for Economic Policy Research.
} 


\section{Articles}

deficit would be limited, since it would depend on higher taxes in the future to repay loans. Eichengreen (1991) added, however, that the mobility of factors of production is not perfect, especially labor, allowing a certain degree of fiscal and tax autonomy to exist.

All of these costs depend on European monetary area optimality - in other words, if states sustain asymmetric demand and supply shocks. Eichengreen (1990) explained that if shocks had an equal impact on all of the countries, the loss of discretionary policies would be less important. Salvatore (1997) replied that the EMS like the EMU had the same problem, namely, adjustment in the case of asymmetric shocks. Several works have been produced to evaluate European state economic convergence, especially in comparison with the U.S. and Canada.

Eichengreen (1991) used two indicators to judge economic convergence between Canadian provinces, U.S. states, and European states, namely, the real exchange rate and price asset variations. The more identical the variations, the more symmetrical the regions were in their reaction to shocks. $\mathrm{He}$ highlighted that, even though the European state converged more than the Canadian provinces, this comparison should not be overstated, since the latter were highly specialized. He concluded that European states were less correlated than U.S. states and therefore sustained asymmetric shocks. Chamie, Deserres, and lalonde (1994) conducted their own comparison with the U.S. and reached the same conclusion.

In two other articles Bayoumi and Eichengreen $(1993,1997)$ tried to provide an index of optimality concerning the European monetary area. There was convergence
Frankel and Rose's Introduction to the Endogeneity of Optimality

between specific countries, but this was not the case when considering the whole monetary area, especially because of the divergence between France and Germany. Von Hagen and Neumann (1994) preferred to compare West German lander and European states in terms of the variance and persistence of real exchange rate shocks. Like Bayoumi and Eichengreen, they concluded that there existed two types of Europe, but they identified a hard core of countries sharing the same business cycles with France and Germany.

Carlino and Defina (1998) focused on the effect of a common monetary policy on U.S. states in order to analyze their reactions. The latter depended on the type of industry, ${ }^{8}$ the number of small companies, and the number of small and large banks. Asymmetric shocks occurred when there were differences between the types of industry and according to the degree of concentration of the banking sector. In other words, European states would react asymmetrically to a common monetary policy in so far as the two previous variables differed. Mélitz and Erkel-Rousse (1995) tried to complete these works using a structural VAR approach to identify structural shocks felt throughout Germany, Spain, France, The Netherlands, and the UK. They distinguished several types of shock: importation prices of raw materials; the relative velocity of domestic and foreign currencies; trade balance; and supply and demand. They concluded that internal and foreign demand shocks remained unstable, which led to a strong disparity between the six countries.

As a result of the weak optimality of European countries relative to the American case, a significant number of works was produced on the OCA criteria, enabling

8 The difference in industries resides in the sensibility of the demand for distinct products. Change in the exchange rate impacts durable goods (house, car...) and non-durable goods (consumable) differently. In the same way, the reaction of industries depends on the need (or not) to purchase goods and the volume of production linked to foreign trade. 


\section{Articles}

adjustment in the case of asymmetric shocks: fiscal federalism and labor as a factor of production (mobility and flexibility of the labor market). The first studied the American case to assess fiscal federalism and its operating procedures. Sala-I-Martin and Sachs (1992) analyzed the aspects of asymmetric shocks that the U.S. federal state could absorb. They estimated it at around a third, either by a reduction in taxes or by an increase in fiscal transfers from other states. They added two important elements: tax variation was the most important phenomenon, whereas fiscal federalism could not absorb the asymmetric shocks. Eichengreen (1991) defended this position, while Von Hagen (1992), Akteson and Bayoumi (1993), and Goodhart and Smith (1992) evaluated redistribution throughout asymmetric shocks of between 10 to 30 cents to 1 dollar in variation in state income. These works concluded that it was necessary to implement such mechanisms in Europe to prevent destabilization of the monetary union.

Inman and Rubinfeld (1992) added that it was difficult to deal with asymmetric shocks at a local level because of capital markets. Indeed, a state must pay back its deficit through a surplus in the future, whereas the burden, expansion of imports, and interest costs of the deficit remain with the state. The existence of a central state is crucial, when the factors of production are perfectly free, to provide public goods at a federal level, since it can tax states similarly. Bayoumi and Masson (1995) contested this perspective by making a distinction between redistributive ${ }^{9}$ and stabilizer $^{10}$ fiscal flux. By drawing a comparison with Canada and the U.S., they stated that the level of stabilization of fiscal transfer achieved a similar degree within the European community and these two countries. According to them, independent tax and fiscal policies were able to perform the same level of stabilization. Pisany-Ferry, Italianer, and Lescures (1992) responded that a federal budget could play the role of an automatic stabilizer. Using Bayoumi and Masson's arguments, they affirmed that tax and transfer variation provided automatic insurance, albeit insufficient to be optimal.

Another possibility remains in the absence of a federal state. Asdrubali, Sorensen, and Yosha (1996) analyzed risk-sharing of the U.S. from shocks on each state's GDP. They noticed that $39 \%$ of these shocks were smoothed by capital markets, $23 \%$ by loan markets, and only $13 \%$ by the federal government. Financial markets thus contributed to $62 \%$ of the absorption of the asymmetric shock. The increase in financial integration in Europe would improve the degree of amortization between state members. However, Akteson and Bayoumi (1993) noted that capital markets were not particularly efficient at providing protection against labor income fluctuations, which depended on the country's economic situation.

Labor, as a factor of production, was the second tool enabling adjustment in the case of asymmetric shocks via two processes: mobility and flexibility. Blanchard and Katz tried to assess labor mobility using U.S. data. Although they concluded that this criterion played a role, it was not so in the European case, and Eichengreen (1991) demonstrated that it would lead to unemployment being perpetuated in some regions. Erkel-Rousse and Mélitz (1995) made the same observation, stating that labor mobility was very weak among European countries, especially because of linguistic and cultural barriers. In the same way, Buiter (1995) highlighted that real wage flexibility was higher in the U.S. than in Europe.

\footnotetext{
9 Pre-shock, reduces long-term income differentials.

${ }^{10}$ Post-shock, reduces short-term regional business-cycle fluctuations.
} 


\section{Articles}

Other authors examined the impact of the exchange rate regime on real wage behavior. No definitive conclusion was drawn: although Alogoskoufis and Smith (1993) provided proof of a positive relationship, Blanchard et al. (1993) concluded that no correlation had been detected on wage behavior in France following the government's decision to stay in the EMS. Likewise, Anderton and Barrell (1995) showed that only Italy's labor market evolved toward more flexibility. Finally, Artis and Omerod $(1994,1995)$ found no significant relationship between a fixed exchange rate regime and higher labor market flexibility.

This list of works enables us to draw two conclusions on endogenous causality. First, Frankel and Rose selected OCA criteria by virtue of their existence and their ability to achieve optimality. For that reason, these potential adjustments, used later in other $E C, 11$ are not integrated in their reasoning, since their development is uncertain. Furthermore, they absorb asymmetric shocks rather than removing them. Only business cycle convergence achieves optimality and avoids asymmetric shocks from the common monetary policy. Thus, the benefits of a monetary union reinforce intra-industry trade, which leads to economic convergence among member states.

Second, endogenous causality draws on the conclusions inherited from the specific case of the European monetary union, which presume that other supplementary conditions work. First, the microeconomic benefits of the introduction of a common currency require a serious and durable commitment on the part of participating countries and institutions in order to function properly. Second, exchange rate instability or incompatibility with Mundell's triangle assume the presence of high capital mobility and developed financial markets.
Frankel and Rose's Introduction to the Endogeneity of Optimality

Third, strong trade integration among European states before monetary union establishment is accepted as a fact while it is the result of historical and specific institutions. Likewise, an important diversification of production is presumed in order to avoid the Canadian specialization. Finally, a reduction in fiscal and tax autonomy seems to be necessary in order to have a common fiscal policy based on the monetary policy model. The operation of $E C$ requires not only the introduction of a common currency but also specific conditions.

\section{A Representation of Specific Economic and Monetary Conditions: The Economic and Monetary Union Case}

Frankel and Rose's papers subscribe to the optimal currency area thought movement and its empirical studies on European monetary unification. The analysis of endogenous causality and its OCA criteria shows that they find their source in these empirical studies, but mostly that they represent the European monetary union's economic and monetary conditions. Thus, the functional limitations of this causality are derived from the EMU influence, with this interpretation reinforced by the hypotheses proposed by Frankel and Rose.

The first point endorsing such a perspective is the link between the Emerson report (1990) and the articles by Frankel and Rose. The document, written within the DirectorateGeneral for Economic and Financial Affairs of the European Commission under the supervision of Sir Emerson, was produced by economists to justify the forthcoming EMU from a theoretical perspective. It also had another objective, which was to convince future participants of the benefits of a

11 Interestingly, EC has been applied to these two OCA criteria: risk-sharing (De Grauwe and Mongelli, 2005) (Adjaoute and Danthine, 2003) (Angeloni et al., 2003); and labor market flexibility (Bertola and Boeri, 2002). 


\section{Articles}

common currency, namely, unions, citizens, business owners, or national administrations.

It should be noted that the Emerson report seems to be the precursor to the endogeneity of optimality:

First, integration as a result of 1992 and EMU leads to changes in industrial structures in the direction of deeper "intraindustry" trade and investment relations, which means that most countries become involved in both exporting and importing the products of many industries. Old-style comparative advantage, in which countries specialize their production in distinct commodities, becomes less important. As a result, sector specific shocks become to a lesser degree country-specific in their impact. (Emerson et al., 1990, p. 24)

It is clear that the articles by Frankel and Rose use the same principles to reach the same conclusion, as demonstrated in the previous sections. The authors quote the Emerson report, stating that they rely on it:

Our hypothesis is that this relationship is positive: the more one country trades with others, the more highly correlated will be their business cycles. This is certainly the relationship pictured by the Commission of the European Communities. (Frankel and Rose, 1997, p. 756)

And, The European Commission (1990) has implicitly recognized this. (Ibid., p. 576 footnote 2)

As is evident, these two articles make clear references to the Emerson report, but mostly the same type of reasoning is used. Frankel and Rose's addition consists of directly naming the endogenous process and thus highlighting the difference between a fixed exchange rate regime and a common currency. However, the most important, and second, point to emphasize is not so much the similarity of the reasoning as Frankel and Rose's support of the Emerson report. Indeed, the latter takes as its basis the economic conditions of European countries to assess and test their optimality. In other words, Frankel and Rose theorize a part of the Emerson report by noticing the endogenous characteristic of the money based on OCA criteria, but they do it in relation to the EMU. Specifically, they build endogenous causality within a specific context. Frankel and Rose's 1997 paper relies on the exact economic conditions of the future European monetary area, and the title illustrates this point: "Is EMU more justifiable ex post than ex ante?" Having described their objective, that is, to prove that OCA criteria are endogenous, Frankel and Rose build their causality by virtue of the economic conditions of European monetary unification.

Indeed, in a footnote in the introduction Frankel and Rose state that they will not "address the important issues of labor mobility or fiscal transfers in this paper" (Frankel and Rose, 1997, p. 754). This perfectly corresponds to the characteristics of the future European monetary union. Furthermore, the authors presume that there are both a high level of trade integration and a diversified productive structure in each country in order for a monetary union to synchronize business cycles and increase diversification. It is clear that if participating countries are economically specialized and do not trade among themselves, the effect of a common currency will be void. Based on these conditions, Frankel and Rose focus on the positive link between monetary union and trade integration to demonstrate that OCA criteria are endogenous. Not only do they argue its existence per se but they also confirm this possibility in the case of the future EMU.

However, Frankel and Rose do not explicitly discuss monetary and fiscal policies when 


\section{Articles}

speaking about endogenous causality. The previous discussion presumes that they defend strict control of monetary issues, but this point needs to be demonstrated. Frankel and Rose share the same ground as Friedman when it comes to the hypothesis on the neutrality of money: "We take it for granted that monetary policy cannot permanently affect either a country's real income level or growth rate; hence our focus on business cycles" (Frankel and Rose, 1998, p. 1011, footnote).

This statement comes from the monetarist revolution in which Friedman (1968) played an important role. This theory calls into question the pertinence of the Phillips curve in its arbitrage between inflation and unemployment. Indeed, money has no impact on the unemployment rate since it is neutral in the long term. Admittedly, in the short term an expansionist policy through monetary issues can have an effect, but in the long term the unemployment rate returns to its previous level. Friedman argues that any expansionist policy that issues a new quantity of money leads to an increase in demand, causing a reduction in the unemployment rate and a rise in general price levels. However, because the real wage diminishes, employees simultaneously demand a salary increase, resulting in dismissal by companies. Consequently, inflation occurs when we return to the conditions that were in place prior to the expansionist policy. ${ }^{12}$

This hypothesis amounts to a statement that monetary and fiscal policies do not impact unemployment and must not undermine price stability. Thus, EC happens not only in the presence of a common currency but also by virtue of a specific monetary institutional arrangement that defends price stability.

This institutional arrangement exactly represents the rules implemented by and after
Frankel and Rose's Introduction to the Endogeneity of Optimality

the Maastricht Treaty in 1992, completed by the Stability and Growth Pact adopted by the European Council on June 17, 1997, in Amsterdam. On the one hand, the European Central Bank (ECB) must hedge against inflation in the euro area. For that reason, it is independent and cannot directly lend to state members or monetize their debt. On the other hand, states must respect the economic convergence criteria: public debt must be inferior to $60 \%$ of the GDP, while public deficit must not overcome $3 \%$ of the GDP.

Seccareccia and Lequain (2006) affirm that financial markets are the true guardians of these fiscal criteria. In the case of nonrespect, they are able to affect states through interest rates on government bonds to compel them to implement certain policies. Besides, the ECB may also react by increasing its interest rate because of an important deficit threatening price stability. It therefore has the means to force states to conform to economic convergence criteria. Monetary issues, either through monetary or fiscal policies, are controlled and oriented toward price stability within the euro area.

Endogenous mechanisms are thus dependent on the monetary arrangements of the EMU and on the economic conditions of state members. Monetary and fiscal policies are oriented toward price stability, and state members need to have diversified production and a high level of trade integration. As a result, the causal mechanisms are only valid in one particular case, namely, European monetary unification. This demonstrates that endogenous causality is not generalizable with other monetary unions. Paradoxically, optimality can be achieved within the European monetary union but not in the case of states having their own national currency.

12 This perfectly corresponds to the hypothesis that money is neutral. See « les pensées monétaires dans l'histoire » (Blanc and Desmedt, 2014) for a historical overview of this theory. 


\section{Articles}

\section{Conclusion}

This article set out to show that the endogenous causality developed by Frankel and Rose required specific economic and monetary conditions in order to operate, namely, those of European monetary unification. The authors affirmed that the introduction of a common currency enabled the synchronization of participating countries' business cycles. The risk of asymmetric shock between countries was no longer possible, which led to optimality. EC emphasizes the causal mechanisms behind this conclusion. It is the product of five optimal currency area criteria interacting: common currency; cost reduction in the exchanges; a trade integration increase; diversification of production; and economic convergence. In the same way, other works argued that the introduction of a common currency developed other OCA criteria: the insurance principle; and flexibility of the labor market. Yet, contrary to the synchronization of business cycles, they only compensated or adjusted to an asymmetric shock.

It has been demonstrated that these causal mechanisms have been built on OCA empirical studies on European monetary unification. The latter could be divided into three questions: the costs and benefits of a common currency; economic divergence within the European monetary union; and adjustment tools. Frankel and Rose selected the first two OCA criteria to develop a causal mechanism explaining that optimality could be achieved ex post, rendering the adjustment criteria useless. Implicitly, Frankel and Rose highlighted the specific conditions of the European monetary unification. The operation of EC thus had requirements that were additional to the establishment of a monetary union.

This interpretation was confirmed by the hypotheses proposed by Frankel and
Rose. They did not consider fiscal transfer and labor mobility in their article, and they only used trade integration to link the microeconomic benefits of the common currency and the synchronization of business cycles. Furthermore, an economic structure that was already diversified was needed in order to reach the desired conclusion. This corresponded to the economic characteristics that were evident throughout European monetary unification.

Monetary conditions were also determinants of the operation of endogenous causality. The latter needed the monetary and fiscal policies committed to price stability that the European monetary union guaranteed. The establishment of central banks oriented toward price stability with economic convergence criteria realized this objective. As a result, endogenous causality only operated in specific economic and monetary conditions, tending to represent those of European monetary unification, and this was not generalizable to other monetary unions.

\section{References}

Adkaoute, K. and Danthine, J. P., 2003. European Financial Integration and Equity Returns: A Theory Based Assessment, in Gaspar, V., Hartmann, P. and Sleijpen, O. (eds), The Transformation of the European Financial System, European central Bank.

Alogoskoufis, G. and Ron, S., 1991. The Phillips Curve, the Persistence of Inflation, and the Lucas Critique: Evidence from Exchange Rate Regimes, American Economic Review, 81 (5), pp. 1254-1275.

Anderton, R. and Barrelle, R., 1995. The ERM and Structural Change in European Labour Markets: A Study of 10 Countries, Weltwirtschaftliches Archiv, 131 (1), pp. 47-66.

Angeloni, I., Ehrmann, M., De Grauwe, P. and Miles, D., 2003. Monetary Transmission in the 


\section{Articles}

Euro Area: Early Evidence, Economic Policy, 18 (37), pp. 469-501.

Artis, Michael and Omerod, P., 1994. Is There an "EMS Effect" in European Labour Markets? In Johnson, C. and Collignon, S. (eds), The Monetary Economics of Europe, London: Pinter, pp. 227-249.

Artis, M. and Omerod, P., 1995. Another Look at the "EMS Effect" in European Labour Markets, unpublished manuscript, European University Institute and University of Manchester.

Asdrubali, P., Sorensen, B. and Yosha, O., 1996. Channels of Interstate Risk Sharing: United States 1963-1990, Quarterly Journal of Economics, 111 (4), pp. 1081-1110.

Atkeson, A. and Bayoumi, T., 1993. Do Private Capital Markets Insure Regional Risk? Evidence from the United States and Europe, Open Economies Review, (4), pp. 303-324.

Bayoumi, T. and Eichengreen, B., 1993. Shocking Aspects of European Monetary Unification ", in Torres, F. and Giavazzi, F. (eds), Adjustment and Growth in the European Monetary Union, Cambridge: Cambridge University Press, pp. 193-230.

Bayoumi, T. and Masson, P., 1995. Fiscal Flows in the U.S. and Canada: Lessons for Monetary Union in Europe, European Economic Review, 39 (2), pp. 253-274.

Bayoumi, T. and Eichengreen, B., 1997. Ever closer to heaven? An Optimum Currency Area Index for European Countries, European Economic Review, Paper and Proceedings of the Eleventh Annual Congress of the European Economic Association, 41 (3), pp. 761-770.

Bertola, G. and Boeri, T., 2002. EMU Labour Markets Two Years On: Microeconomic Tensions and Institutional Evolution, in Buti, M. and Sapir, A. (eds), EMU and Economic Policy in Europe: The Challenge of the Early Years, Edward Elgar, Aldershot, pp. 249-280.
Frankel and Rose's Introduction to the Endogeneity of Optimality

Blanc, J. and Desmedt, L., 2014. Les pensées monétaires dans l'histoire : l'Europe, 15171776, Bibliothèque de l'économiste 6 . Paris : Classiques Garnier.

Blanchard, O., Muet, P. A., Grilli, V. and Vial, P., 1993. Competitiveness Through Disinflation: An Assessment of the French Macroeconomic Strategy, Economic Policy, 8 (16), pp. 11-56.

Buiter, W., 1995. Macroeconomic Policy During the Transition to Monetary Union, CEP Discussion Papers dp0261, Centre for Economic Performance, LSE.

Carlino, G. and Defina, R., 1998. Monetary Policy and the U.S. States and Regions: Some Implications for European Monetary Union, Federal Reserve Bank of Philadelphia Working Paper No. 98-17.

Chamie, N., Deserres, A. and Lalonde, R., 1994. Optimum Currency Areas and Shock Asymmetry: A Comparison of Europe and the United States, Bank of Canada Working Paper No. 94/1.

De Grauwe, P. and Mongelli, F., 2005. Endogeneities of Optimum Currency Areas: What brings Countries Sharing a Single Currency Closer together? Working Papers de Economia (Economics Working Papers). Departamento de Economia, Gestão e Engenharia Industrial, Universidade de Aveiro.

Eichengreen, B., 1990a. Costs and Benefits of European Monetary Unification ", Centre for Economic Policy Research Discussion Paper No. 353.

Eichengreen, B., 1990b. One Money for Europe? Lessons from the U.S. Currency Union, Economic Policy, 5 (10), pp. 117-187.

Eichengreen, B., 1991. Is Europe an Optimum Currency Area? National Bureau of Economic Research Working Paper No. 3579.

Eichengreen, B., 1992. Should the Maastricht treaty be saved? Princeton Studies in International Finance, No. 74, International 


\section{Articles}

Finance Section, Princeton University, December.

Eichengreen, B. and Frieden, J., 1993. "The Political Economy of European Monetary Unification: An Analytical Introduction ", Economics and Politics, 5 (2), pp. 85-104.

Emerson, M., Delors, J. and Henning, C., 1990. One market, One Money. An evaluation of the poential benefits and costs of forming an economic and monetary union, Commission of the European Communities, DirectorateGeneral for Economic and Financial Affairs, 44.

Eudey, G., 1998. Why is Europe Forming a Monetary Union? Business Review - Federal Reserve Bank of Philadelphia, issue Nov, pp. 13-21.

Frankel, J. and Rose, A., 1997. Is EMU more Justifiable Ex Post than Ex Ante? European Economic Review, Paper and Proceedings of the Eleventh Annual Congress of the European Economic Association, 41 (3-5), pp. 753-760.

Frankel, J. and Rose, A., 1998. The Endogeneity of the Optimum Currency Area Criterion, The Economic Journal, 108 (449), pp. 1009-1025.

Friedman, M., 1968. The Role of Monetary Policy, The American Economic Review, 58 (1), pp. 1-17.

Goodhart, C. and Smith, S., 1992. Stabilization in The Economics of Community Public Finance, European Economy review, Special Issue (5), pp. 417-456.

Ingram, J. C., 1962. Regional Payments Mechanisms: The Case of Puerto Rico, Chapel Hill: University of North Carolina Press.

Inman, R. and Rubinfeld, D., 1992. Fiscal Federalism in Europe: Lessons from the United States, European Economic Review, 36 (2), pp. 654-660.

Jonung, L. and Drea, E., 2010. The Euro: It can't happen, it's a bad idea, it won't last. US Economists on the EMU, 1989-2002, European
Economy - Economic Paper. Directorate General Economic and Financial Affairs (DG ECFIN), European Commission.

Jordan, J., 1997. Money, Fiscal Discipline and Growth ", Economic Commentary September: 1-4. Federal Bank of Cleveland.

Kenen, P. 1969. The Theory of Optimum Currency Areas: An Eclectic View, in Mundell, R. and Swoboda, A. (eds), Monetary Problems of the International Economy, University Press of Chicago, pp. 40-61.

Klein, M., 1998. European Monetary Union, New England Economic Review, March/April: 3-12. Federal Reserve Bank of Boston.

Krugman, P., 1993. " Lessons of Massachusetts ", in Torres, F. and Giavazzi, F. (eds), Adjustment and Growth in the European Monetary Union, Cambridge New York Melbourne: Cambridge University Press, pp. 241-270.

Lequain, M. and Seccareccia, M., 2006. What can we learn from the EMU Model? Lessons for Canada and Britain, Current Politics and Economics of Europe, 17, pp. 289-317.

Lucas, R., 1972. Expectations and the Neutrality of Money, Journal of Economic Theory, 4 (2), pp. 103-24.

Masson, P. and Taylor, M., 1992. Issues in the Operation of Monetary Unions and Common Currency Areas, in Goldstein, M. et al. (eds), Policy Issues in the Evolving International Monetary System, Washington, D.C.: International Monetary Fund, Occasional Paper No. 96, pp. 39-72.

McKinnon, R., 1963. Optimal Currency Areas, The American Economic Review, 53 (4), pp. 717-725.

Mundell, R., 1961. A Theory of Optimum Currency Areas, The American Economic Review, 51 (4), pp. 657-665.

Neumann, M. and Von Hagen, J. 1994. Real Exchange Rates Within and Between Monetary Unions: How Far Away is EMU, 


\section{Articles}

Review of Economics and Statistics, 76 (2), pp. 236-244.

Pisany-Ferry, J., Italianer, A. and Lescure, R., 1992. Stabilization Properties of Budgetary Systems: A Simulation Analysis ", in European Economy, The Economics of Community Public Finance, Reports and Studies, 5, pp. 511-38.

Sala-i-Martin, X. and Sachs, J., 1992. Fiscal Federalism and Optimum Currency Areas: Evidence for Europe from the United States, in Canzoneri, M., Grilli, V. and Masson, P. (eds), Establishing a Central Bank: Issues in Europe and Lessons from the United States, Cambridge: Cambridge University Press, pp. 195-220.

Salvatore, D., 1997. The Common Unresolved Problem with the EMS and EMU, American Economic Review, 87 (2), pp. 224-226.

Salvatore, D. and Fink, G., 1999. Benefits and Costs of European Economic and Monetary Union, Brown Journal of World Affairs, 4 (2), pp.187-194.
Frankel and Rose's Introduction to the Endogeneity of Optimality

Tavlas, G., 1993. The "New" Theory of Optimum Currency Areas, World Economy, 16 (6,) pp. 663-685.

Tavlas, G., 1994. The Theory of Monetary Integration, Open Economies Review, 5 (2), pp. 211-230.

Vincensini, C. and Taugourdeau E., 2009. La justification économique de l'Union économique et monétaire: ex ante, ex post ou inexistante? Revue française d'économie, 24 (2), pp. 57-83.

Von Hagen, J., 1992. Fiscal Arrangements in a Monetary Union: Evidence from the U.S., in Fair, D. and De Boissieu, C. (eds), Fiscal Policy, Taxation and the Financial System in an Increasingly Integrated Europe, Kluwer: Dordrecht, pp. 337-360.

Whitt, J., 1997. Decision Time for European Monetary Union, Economic Review, third quarter, Federal Reserve Bank of Atlanta, pp. 20-33. 